\title{
RENDERING UNTO GAESAR: RELIGIOUS PUBLISHERS AND THE PUBLIC BENEFIT RULE
}

\author{
R. Charles Millek ${ }^{\dagger}$
}

Piety is no defense to the assessments of the tax collector.

-Scripture Press Foundation v. United States, 285 F.2d 800, 804

(Ct. Gl. 1961)

Religion creates some of its most intractable problems for the State when it engages in commercial or other traditionally secular activities. Religious organizations run schools, operate hotels and restaurants, and invest in private enterprise. They also publish books. Each of these pursuits raises difficult questions, for under the religion clauses of the Constitution 1 the State must avoid both lending its imprimatur to such activities and abridging opportunities for free religious expression. Especially difficult for the State to accommodate are requests by religious organizations to be free of the burdens of taxation. The extent to which the State may encourage the free exercise of religion by granting tax exemptions, without transgressing the boundaries of the establishment clause, is a thorny issue that has evaded clear resolution.

Recently the Court of Appeals for the Third Circuit confronted this issue in Presbyterian \& Reformed Publishing Co. v. Commissioner (PE्SR Publishing). ${ }^{2}$ Relying on the statutory language of section 501(c)(3) of the Internal Revenue Code, ${ }^{3}$ the court of appeals granted tax-exempt status to a company engaged in the publication of books that advance the beliefs of the Orthodox Presbyterian Church. ${ }^{4}$ In doing so, however, the court applied traditional doctrine and ignored guidance recently given by the Supreme Court in Bob Jones University v. United States. ${ }^{5}$

This Comment will address the standards currently used to evaluate the tax status of religiously affiliated organizations, and suggest that

† B.A. 1980, Harvard University; J.D. 1985, University of Pennsylvania. The author wrote this Comment while a student at the University of Pennsylvania Law School.

1 U.S. Const. amend. I, cl. 1 (providing that "Congress shall make no law respecting an establishment of religion, or prohibiting the free exercise thereof").

743 F.2d 148 (3d Cir. 1984).

3 I.R.C. § 501(c)(3) (1982).

- PER Publishing, 743 F.2d at 159.

s 461 U.S. 574 (1983). 
the public benefit rule set forth by the Supreme Court in Bob Jones is a more appropriate device for deciding which organizations should be granted exemptions. Part I examines the particularly difficult case of religious publishing houses presented in $P \mathcal{E} R$ Publishing. The second part of the Comment reviews the shifting standards propounded by the courts and the Internal Revenue Service for determining exemptions under section 501(c)(3). Part III traces the development of the public benefit rule that emerged in Bob Jones. Finally, part IV argues that the public benefit rule should be applied in all 501(c)(3) exemption cases and that this rule is particularly effective in scrutinizing religious profitmakers.

\section{Presbyterian \& Reformed Publishing Co. v. Commissioner ${ }^{6}$}

The Presbyterian and Reformed Publishing Company (P\&R) began as a small printing establishment closely linked with the Orthodox Presbyterian Church (OPG). Since its incorporation in 1931, P\&R has been dedicated to publishing books in order to disseminate and defend the beliefs of the OPC. P\&R was granted tax-exempt status by the IRS in 1939 , based on the understanding that its " income is derived from subscriptions, contributions and gifts and is used to defray maintenance and general operating expenses.' "7

As a result of dramatic increases in the sales of certain of its books, P\&R's publishing enterprise began to grow rapidly in the early 1970's. The company accumulated a cash surplus throughout the mid-1970's, intending to use some of this money to build new office and storage facilities. In $1979, \mathrm{P} \& \mathrm{R}$ had its most profitable year, earning over $\$ 300,000$ in gross profits. ${ }^{8}$ P\&R's expansion during this period prompted an investigation and audit by the IRS. ${ }^{\circ}$ The IRS revoked $P \& R^{\prime}$ 's tax-exempt status in 1980, asserting that $P \& R$ "was not 'operating exclusively for purposes set forth in 501(c)(3)' and was 'engaged in a business activity which is carried on similar to a commercial enterprise." "10 The Tax Court affirmed this determination in late 1982,"11 finding specifically that $P \& R$ 's business practices placed it in "competition with commercial publishers."12 This opinion was reaffirmed by the

6 743 F.2d 148 (3d Cir. 1984).

7 Id. at 150 (quoting IRS determination of December 12, 1939).

8 Id. at 151.

- Id.

${ }^{10}$ Id. (quoting IRS revocation letter of October 28, 1980).

II See Presbyterian \& Reformed Publishing Co. v. Commissioner, 79 T.C. 1070 (1982), rev'd, 743 F.2d 148 (3d Cir. 1984).

${ }^{12}$ Id. at 1085 . 
Tax Court in 1983 on P\&R's motion for reconsideration. ${ }^{13}$

In its appearance before the Court of Appeals for the Third Circuit, $P \& R$ sought to establish that the mere presence of profitmaking does not command a revocation of tax-exempt status. ${ }^{14} \mathrm{P} \& \mathrm{R}$ contended that an examination of its activities as a whole would lead to the conclusion that it was "organized and operated exclusively for religious ... purposes."15

The Third Circuit agreed with P\&R's contentions. In his opinion for the three-judge panel, Judge Arlin Adams identified the principal issue as one of determining the point at which "successful operation of a tax-exempt organization should be deemed to have transformed that organization into a commercial enterprise and thereby to have forfeited its tax exemption." "'6 Troubled by the rigidity of the Tax Court's inquiry, ${ }^{17}$ the Third Circuit evaluated P\&R's exemption under a twopronged test: (1) what is the purpose of the organization; and (2) to whose benefit does its activity inure? ${ }^{18}$

The court first addressed the question of inurement. Section 501(c)(3) requires that "no part of the [organization's] net earnings ... [may] inure . . . to the benefit of any private shareholder or individual" if that organization is to be relieved of the burden of taxation. ${ }^{18}$ The court found "no basis in the record for concluding that P\&R's increased commercial activity inured to the personal benefit of any individual," largely because none of the eight paid employees received annual salaries exceeding $\$ 16,000$. $^{\mathbf{2 0}}$

The purpose prong of the test was more difficult for the court to

${ }^{13}$ See 743 F.2d at 152 (discussing Presbyterian \& Reformed Publishing Co., No. 1759-81X (T.C. Apr. 8, 1983)).

14 $C f$. Aid to Artisans, Inc. v. Commissioner, 71 T.C. 202, 211 (1978) (noting "that the presence of profitmaking activities is not per se a bar to qualification [for exemption under section 501(c)(3)] if the activities further or accomplish an exempt purpose") (citations omitted).

18 I.R.C. § 501(c)(3) (1982).

16743 F.2d at 152.

17 The Tax Court's inquiry focused on a number of different considerations in connection with its finding of nonexemption: increase in commercial activity, accumulation of capital, profitability of the organization, and development of a professional staff, as well as lack of affiliation with any particular church. The Third Circuit felt that focusing solely on these indicia rather than on the record as a whole was too inflexible an approach to the problem. See id. at 152, 158.

${ }_{18}$ See id. at 152.

18 I.R.C. $\$ 501$ (c)(3) (1982); see also Founding Church of Scientology v. United States, 412 F.2d 1197, 1199-200, 1202 (Ct. Cl. 1969) (articulating standards for findings of inurement in cases involving section 501(c)(3)), cert. denied, 397 U.S. 1009 (1970); Bubbling Well Church of Universal Love v. Commissioner, 670 F.2d 104, 10506 (9th Cir. 1981) (denying section 501(c)(3) exemption because of unreasonable salaries paid to three director-employees).

20743 F.2d at 154. 
resolve. Section 501 (c)(3) demands that an enterprise be organized and operated exclusively for an exempt purpose. ${ }^{21}$ This is a requirement that, even at first glance, appears susceptible to flexible application. What is meant by "exclusively," and how can an accurate evaluation of such a factor ever be made? Seldom will an organization applying for a section 501(c)(3) exemption state in its articles of incorporation that its organizational purpose is not exclusively religious, charitable, or educational. The courts and the IRS must therefore appraise the day-to-day operations of the organization to determine if it behaves like a normal profitmaking enterprise. They must ask whether the organization's continued existence depends at least in part on the receipt of profits.

The Court of Appeals identified and discussed two common indicia of nonexempt activity. First, the court considered P\&R's lack of affiliation with any particular church. The Tax Court below had found $P \& R$ 's nondenominational character a persuasive factor in denying the publisher exempt status. ${ }^{22}$ The Third Circuit dismissed this consideration as indeterminate, noting that even the Tax Court had recognized that " the denominational or nondenominational character of an organization has never been a controlling criterion." "23 Second, the court considered the accumulation of profits by $P \& R$. The presence of substantial profits has always been an important factor in the assessment of exempt status. "24 "There is no doubt," the court said, "that unexplained accumulations of cash may properly be considered as evidence of commercial purpose." 25 Notwithstanding the fact that P\&R had amassed considerable excess capital, ${ }^{26}$ the professed need for expansion of its physical plant was deemed to be an acceptable explanation for profit accumulation. The court believed that expansion, as a means to more efficient dissemination and greater influence, "should not jeopardize the tax-exempt status of organizations which remain true to their stated goals." ${ }^{27}$ The Third Circuit thus concluded that $P \& R$ passed both parts of its two-pronged test and was therefore entitled to a tax

21 The Supreme Court, in Better Business Bureau v. United States, 326 U.S. 279 (1945), articulated the exclusivity standard: "[T]he presence of a single [non-exempt] purpose, if substantial in nature, will destroy the exemption . . . Id. at 283. The Third Circuit in $P \mathcal{E}^{\circ} R$ Publishing noted that this rule may involve a court in the difficult task of determining unspoken motives. Since widely differing conclusions about motives can be drawn from the same set of actions, the rule allows courts considerable flexibility. See PER Publishing, 743 F.2d at 155.

22 See 743 F.2d at 156.

${ }^{23}$ Id. (quoting Presbyterian \& Reformed Publishing Co., No. 1759-81X, slip op. at 5 (T.C. Apr. 8, 1983) (decision on P\&R's motion for reconsideration)).

${ }_{24}$ See infra notes 35-58 and accompanying text.

2s PER Publishing, 743 F.2d at 157.

${ }^{26}$ At its peak in $1976, P \& R$ had over $\$ 400,000$ cash on hand. 79 T.C. at 1078.

27743 F.2d at 158. 
exemption under section 501(c)(3).

Although more will be said of the case law development of the section 501(c)(3) exemption in part II of this Comment, ${ }^{28}$ the $P \mathscr{E} R$ Publishing court's treatment of one related precedent should be mentioned here. The court cited, and rejected, Fides Publishers Association v. United States, ${ }^{29}$ a case strikingly similar to $P \mathcal{E} R$ Publishing in several ways. Like P\&R, Fides Publishing had modest beginnings, but experienced rapid growth over a brief period of time. Moreover, Fides was also engaged primarily, if not solely, in publishing activities. The district court in Fides Publishing found that the proper inquiry under section 501(c)(3) is a "search for a single non-exempt purpose, substantial in nature, which would destroy the exemption."30 The court then identified such a purpose: "the publication and sale of religious literature at a profit." 31 This profitmaking purpose was sufficient to justify the revocation of Fides' tax exemption. ${ }^{32}$

Fides Publishing and PESR Publishing stand at opposite ends of a confusing spectrum of exemption decisions. Whether the continued accrual of profits in itself compels a revocation of tax-exempt status is but one of a number of issues that have been answered inconsistently by the courts. The next part of this Comment traces the development of exemptions under section 501(c)(3) and points out the infirmities in the tests for exemption that are now applied.

\section{Standards For EXemption Under Section 501(c)(3)}

Section 501(c)(3) has its origins in exemptions that are as old as federal income taxation itself. The earliest discussions of such an exemption date back to the income tax act of $1894 .^{33}$ In its present form, section 501(c)(3) lists eight different categories of organizations eligible for the exemption:
(a) An organization described in subsection
(c) ...

28 See infra text accompanying notes 35-58.

28 263 F. Supp. 924 (N.D. Ind. 1967). The Third Circuit stated that "[i]nsofar as Fides is read to suggest a per se profits rule, we decline to accept its reasoning as contrary to the history and language of $\S 501$ (c)(3)." 743 F.2d at 156 n.5.

so Fides Publishers, 263 F. Supp. at 935.

31 Id.

32 See id.

ss See Tariff of 1894 , ch. 349, $\S 32,28$ Stat. 509, 556. This income tax act was subsequently held unconstitutional, in Pollack v. Farmers' Loan \& Trust Co., 158 U.S. 601 (1895), for reasons unrelated to the exemption provision. Similar exemptions have appeared in every income tax act since the adoption of the sixteenth amendment. See Bob Jones Univ. v. United States, 461 U.S. 574, 589 n.14 (1983) (giving an overview of the history of the section 501 (c)(3) exemption). 
shall be exempt from taxation ....

(c) The following organizations are referred to in subsection (a): . . . (3) Corporations, and any community chest, fund, or foundation, organized and operated exclusively for religious, charitable, scientific, testing for public safety, literary, or educational purposes, or to foster national or international sports competition ...., or for the prevention of cruelty to children or animals, no part of the net earnings of which inures to the benefit of any private shareholder or individual .... ${ }^{34}$

Thus, to be eligible for exemption under this section, an organization must be engaged exclusively in one or more of the eight enumerated activities.

This misleadingly simple formulation has led the courts down a number of twisted paths in search of coherent distinctions. The first Supreme Court case to deal directly with this exemption was Trinidad v. Sagrada Orden. ${ }^{35}$ The Sagrada Orden-a Philippine corporation engaged principally in missionary work-traded wine, chocolate, and other articles and collected rents from various properties. The United States claimed that these activities necessarily involved the corporation in commercial enterprise and precluded tax-exempt status.

In its evaluation of the Sagrada Orden's business, the Supreme Court first recognized that "a corporation may be organized and operated exclusively for religious, charitable, scientific, or educational purposes, and yet have a net income." ${ }^{\prime 36}$ The Court then asserted that the destination of the income was the ultimate test for exemption. Finding that the Sagrada Orden assiduously applied all of its income to its religious, educational, and charitable endeavors, the Court upheld the exemption: "That the transactions yield some profit is in the circumstances a regligible factor. Financial gain is not the end to which they are directed."s7 In other words, according to the Court in Trinidad, that profit is derived from an organization's commercial activities does not of itself negate an otherwise valid exemption. ${ }^{38}$

34 I.R.C. § 501(c)(3) (1982).

s5 263 U.S. 578 (1924) (construing Act of Oct. 3, 1913, ch. 16, § II(G)(a), (M), 38 Stat. 114, 172, 180 (current version at I.R.G. $\S 501(c)(3))$ ).

${ }^{36}$ Trinidad, 263 U.S. at 581.

st Id. at 582 .

${ }^{38}$ The converse, of course, is also true: "[F]ailure to show a profit does not per se entitle a corporation to exempt status . . . " Elisian Guild, Inc. v. United States, 412 F.2d 121, 125 (1st Cir. 1969). 
The next significant Supreme Court decision in this area came in Better Business Bureau v. United States. ${ }^{39}$ Petitioner was an organization devoted to helping other businesses function in an efficient and profitable manner. It claimed that its exclusive purpose was thus "educational" and that it was entitled to exemption from taxation. The Supreme Court, however, disagreed with this contention, and instead characterized the Better Business Bureau's purpose as commercial. To the Court, it was "apparent beyond dispute that an important, if not the primary, pursuit of petitioner's organization is to promote not only an ethical but also a profitable business community."40 Further, "in order to fall within the claimed exemption, an organization must be devoted to educational purposes exclusively. This plainly means that the presence of a single noneducational purpose, if substantial in nature, will destroy the exemption regardless of the number or importance of truly educational purposes."41

Better Business Bureau and Trinidad were the only Supreme Court opinions in this area prior to 1983. They have provided lower courts with precious little guidance. Trinidad implies that profits are irrelevant in the calculation of tax-exempt status, as long as the "destination of income" is appropriate. But how is a lower court to determine acceptable destinations for surplus profits, and at what point must an extremely profitable enterprise, which is probably competing with nonexempt businesses, forfeit its exemption? Better Business Bureau exhibits similar deficiencies. Its instruction to look for the presence of any substantial nonexempt purpose begs the entire question. If an organization must operate "exclusively" for a prescribed purpose, then undoubtedly any other substantial motivation will invalidate the exemption. ${ }^{\mathbf{} 2}$

Equipped with this meager guidance from the Supreme Court, the state and lower federal courts have reached decisions that are nearly impossible to reconcile under a coherent standard. Several examples will suffice to demonstrate the extent of this problem.

First, consider the issue presented in Scripture Press Foundation v. United States. ${ }^{43}$ In Scripture Press, a religious publishing corpora-

s9 326 U.S. 279 (1945). The Better Business Bureau's claim actually arose under I.R.C. $\$ 811$ (b)(8), the exemption provision for Social Security assessments. The operative language of the section closely follows that of section 501(c)(3).

10 Better Business Bureau, 326 U.S. at 283.

41 Id.

12 Neither Trinidad nor Better Business Bureau yields a clear answer to the question presented in PESR Publishing. Would the Trinidad Court find the reinvestment of surplus capital into increased storage and office space a legitimate destination of income? Similarly, would the Better Business Bureau Court find P\&R's apparent concern with profits a nonreligious purpose "substantial in nature"?

13 285 F.2d 800 (Ct. Cl. 1961). 
tion claimed that it was "operated exclusively" for an exempt purpose, since the express goal of its business was the advancement of the Protestant Sunday Schools of America. ${ }^{44}$ The United States disagreed and claimed that the plaintiff's predominant motive was actually the preparation and sale of religious literature. ${ }^{45}$ Instead of focusing on the destination of income, as suggested in Trinidad, or identifying a separate nonexempt purpose, as in Better Business Bureau, the Scripture Press court fashioned a new test. The proper inquiry, the court said, was whether "the sale of religious literature by the plaintiff in this case [is] incidental to the plaintiff's religious purposes."46 Answering the question in the negative, the Court of Claims held that "the sale of these materials, however religiously inspired, involved the plaintiff directly in the conduct of a trade or business for profit." 47

The approach employed by the Tax Court in B.S.W. Group, Inc. v. Commissioner ${ }^{48}$ represents yet another line of attack on the same problem. The B.S.W. Group claimed that its sole activity was the provision of consulting services for a fee to nonprofit, rural groups seeking advice on health and housing issues. ${ }^{48}$ The Tax Court refused to grant B.S.W. an exemption under section 501(c)(3), primarily because B.S.W. failed to demonstrate that its service would not compete directly with commercial consulting companies. "Competition with commercial firms," the court ruled, "is strong evidence of the predominance of nonexempt commercial purposes." was apparently dispositive.

A final example of the various approaches to section 501(c)(3) is found in Incorporated Trustees of the Gospel Worker Society $v$. United States. ${ }^{51}$ In this case, a federal district court considered the tax-exempt status of a "Society" whose membership comprised twenty-three mostly elderly women living in a home maintained at the expense of the Society. The only discernible activity of the organization, apart from main-

44 See id. at 802.

15 See id.

${ }^{46} I d$. at 804 (emphasis added).

47 Id. at 806. A number of other courts have used a similar line of analysis. See, e.g., American Inst. for Econ. Research v. United States, 302 F.2d 934, 938 (Ct. Cl. 1962) ("By the sale of these publications and services, plaintiff has entered, unwittingly or not, a business."); $c f$. Saint Germain Found. v. Commissioner, 26 T.C. 648, 658 (1956) (upholding an exemption for an organization whose sales of literature and other income-producing activities were "closely associated with, and incidental to, [its] religious purposes").

48 T.C. 352 (1978).

49 See id. at 353.

so Id. at 358.

s1 510 F. Supp. 374 (D.D.C.), affd mem., 672 F.2d 894 (D.C. Cir. 1981), cert. denied, 456 U.S. 944 (1982). 
tenance of the home, was the publication of religious literature through its Gospel Press. The Press was managed by employees who were not members of the Society; the contribution of Society members was limited to proofreading. The printing operations had been extremely successful, resulting in an accumulated surplus of over $\$ 5.3$ million by $1978 .{ }^{.2}$

The district court, in denying tax-exempt status to the Society, found that a combination of factors "present[ed] a picture of a publishing enterprise the primary purpose of which is profits, not salvation."ss Among the factors influencing the court's decision were a huge accumulation of undedicated profits, an abrupt increase in the salaries of the Society's top officers, and the fact that the Society was in direct competition with a number of commercial publishers. ${ }^{54}$ The court further observed that "other organizations whose primary activities consist of the publication and distribution of religious literature at a profit have consistently been held liable for the tax on their income, however religiously inspired the sale of such literature might be."55

One begins to wonder, after reading a number of cases involving section 501(c)(3), if there might not be some recondite touchstone, invisible to the nonjudicial eye, on which the courts are relying to distinguish exempt and nonexempt organizations. Reconciling PER Publishing and Elisian Guild with Fides Publishing, Scripture Press, and Gospel Worker Society requires some absurd hairsplitting. The factual differences among these cases can support neither the inexplicably diverse results nor the invocation in each case of different standards ${ }^{56}$ for

s2 Id. at 376 .

53 Id. at 380 .

st See id. at $378-79$.

so Id. at 380. As support for the proposition, the court cited Scripture Press Foundation and Christian Manner Int'l, Inc. v. Commissioner, 71 T.C. 661 (1979). In Christian Manner, the Tax Court found that "petitioner's primary activity was the distribution, promotion, and sale" of religious books. Id. at 668. The court then held that this activity was substantially commercial in nature, since "[p]rofits admittedly are petitioner's goal and most, if not all, of petitioner's efforts have been directed toward its realization." Id. at 670 .

It is surprising that the district court in Gospel Worker Society made this broad generalization in view of a number of factually similar cases in which exemptions were granted to religious enterprises. See, e.g., Elisian Guild, Inc. v. United States, 412 F.2d 121, 125 (1st Cir. 1969) (exemption granted despite build-up of inventory that was "extraordinary in view of [the organization's] past sales history"); Pulpit Resource v. Commissioner, 70 T.C. 594, 611 (1978) ("The fact that petitioner intended to make a profit, alone, does not negate that petitioner was operated exclusively for charitable purposes."); Saint Germain Found. v. Commissioner, 26 T.C. 648, 658 (1956) (income from sale of religious publications found incidental to religious purposes manifested by organization's religious classes and conclaves).

BB Approaches taken in these cases include the "destination of income" test (Trinidad), the "substantial nonexempt purpose" test (Better Business Bureau), the two- 
assessing the taxability of organizations. ${ }^{37}$

Lacking any evidence of an overarching doctrine, one is forced to conclude that the courts have simply been asking, on a case-by-case basis, whether a particular petitioner is "acting" like a charitable, or instead like a commercial, organization. Much of this analysis depends on the subjective intent of the organization claiming an exemption. Because courts rarely have direct evidence of intent, they must decide these cases by evaluating external behavior that has little to do with the animating purpose behind the enterprise.

A certain amount of sympathy is due a court that undertakes an examination of these external factors. Even the most charitable of organizations must behave in a sensible and sometimes shrewd manner that might easily be termed "commercial." Conversely, even the most capitalistic business may at times, and with sufficient incentives, display altruistic tendencies. Requiring courts to disentangle these threads of behavior and to divine which is of deeper hue is to invite inconsistent results.

Thus stood section 501 analysis prior to 1983. In that year, the Supreme Court decided Bob Jones University $v$. United States. ${ }^{58}$ The next part of this Comment will review the Court's decision in Bob Jones to determine whether it provides guidance for subsequent decisions on the tax-exempt status of charitable organizations.

\section{Revisions UNDER Bob Jones University v. United States}

\section{A. The Application of Section 501(c)(3) to Discriminatory Schools}

The appearance of Bob Jones University before the Supreme Court represented the culmination of thirteen years of turmoil surrounding the tax-exempt status of discriminatory private schools and colleges. As originally applied, section 501(c)(3) provided tax exemp-

pronged "inurement/purpose" test ( $P \mathcal{E} R$ Publishing), the "incidental nature" test (Scripture Press), the "combined factors" approach (Gospel Worker Society), the examination of competition with other, commercial enterprises (B.S.W. Group), and a per se profits rule (Fides Publishers).

${ }^{57}$ Little aid in the way of unifying principles has been provided by the Internal Revenue Service. For example, a frequently cited regulation has only this to say about the "operational test" of section 501(c)(3):

An organization will be regarded as "operated exclusively" for one or more exempt purposes only if it engages primarily in activities which accomplish one or more of such exempt purposes specified in section 501 (c)(3). An organization will not be so regarded if more than an insubstantial part of its activities is not in furtherance of an exempt purpose.

26 C.F.R. § 1.501(c)(3)-1(c)(1) (1984).

s8 461 U.S. 574 (1983). 
tions to religious schools regardless of their policies of racial discrimination. In 1970, however, following the issuance of a preliminary injunction by the District Court for the District of Columbia, ${ }^{59}$ the IRS began to refuse claims of tax-exempt status by religious schools that practiced racial discrimination. The IRS set forth its revised policy in Revenue Ruling $71-447,60$ in which it concluded that section 501(c)(3) contemplated a common law notion of charity for all exempted organizations and that discriminatory practices by religious schools were contrary to public policy and thus not "charitable."61

The federal courts quickly upheld this IRS policy change. In Green v. Connally, ${ }^{62}$ the District Court for the District of Columbia upheld the denial of tax-exempt status for discriminatory private schools in Mississippi. Likening the schools to educational trusts, the court emphasized society's traditional refusal to sanction educational trusts that accomplish purposes contrary to public policy. ${ }^{63}$

Bob Jones University had actually been before the Supreme Court nine years earlier, on a related issue, in Bob Jones University v. Simon. ${ }^{64}$ In this earlier case, Bob Jones sought to enjoin the IRS from revoking its tax-exempt status. The Court ruled that section 7421(a) of the Internal Revenue Code ${ }^{65}$ precluded the school from obtaining an injunction before any tax had been assessed. ${ }^{68}$

The IRS revoked the tax-exempt status of Bob Jones University in 1976. Bob Jones paid a nominal tax and then sued for a refund. ${ }^{67}$ The school's claim was greeted favorably in district court, where it was ordered that the University's tax payment be refunded. ${ }^{68}$ The Court of Appeals for the Fourth Circuit, relying heavily on the common law

58 Green v. Kennedy, 309 F. Supp. 1127 (D.D.C.), appeal dismissed sub nom. Cannon v. Green, 398 U.S. 956 (1970).

60 1971-2 C.B. 230.

61 Id. at 231.

62330 F. Supp. 1150 (D.D.C.), affd per curiam sub nom. Coit v. Green, 404 U.S. 997 (1971).

6s Id. at 1159-61.

64 416 U.S. 725 (1974).

es I.R.C. § 7421(a) (1982).

${ }^{66}$ See Bob Jones Univ. v. Simon, 416 U.S. at 749.

67 Bob Jones paid a total of $\$ 21.00$ for 1975 , reporting the tax for one employee; this enabled the University to sue in federal district court for a refund. The United States government counterclaimed for almost $\$ 500,000$ in unpaid taxes. See Bob Jones Univ. v. United States, 461 U.S. at 582.

${ }^{68}$ Bob Jones Univ. v. United States, 468 F. Supp. 890 (D.S.C. 1978), rev'd, 639 F.2d 147 (4th Cir. 1980), affd, 461 U.S. 574 (1983). The district court held that revocation of the university's tax-exempt status exceeded the delegated powers of the IRS and violated both the establishment and free exercise clauses of the first amendment. See id. at 907. 
definition of "charitable" advanced in Green $v$. Connally, ${ }^{69}$ reversed the decision. ${ }^{70}$ The Fourth Circuit also held that the IRS had acted within its authority, ${ }^{71}$ and that neither of the religion clauses of the first amendment was violated by the revocation of Bob Jones' tax-exempt status. ${ }^{72}$ Bob Jones appealed this decision, and the Supreme Court granted certiorari. ${ }^{73}$

The Bob Jones case received a great deal of critical attention even before it reached the Supreme Court. Most commentators considered the case in terms of the tremendous conflict between two fundamental values: access to equal, nondiscriminatory education on the one hand, and free exercise and establishment clause guarantees under the first amendment on the other. The commentary, not surprisingly, varied greatly in its proposed solutions to the problem. Some writers felt that both religion clauses had been violated by the actions of the IRS; ${ }^{74}$ others believed that the IRS was incapable of accurately assessing the abridgment of first amendment rights and should thus be prohibited from making these exemption decisions. ${ }^{75}$ Still others argued that the free exercise and establishment clauses do not preclude denial of tax exemptions to schools that discriminate. ${ }^{76}$ Against this diverse critical background Bob Jones University was heard by the Supreme Court.

${ }^{69}$ Bob Jones Univ. v. United States, 639 F.2d 147, 150-51 (4th Cir. 1980) (discussing Connally, 330 F. Supp. at 1156-60), affd, 461 U.S. 574 (1983).

70 See id. at 149.

71 See id. at 150-53.

72 See id. at 153-55.

73 See 454 U.S. 892 (1981), granting cert. to Bob Jones Univ. v. United States, 639 F.2d 147 (4th Cir. 1980). Goldsboro Christian Schools, Inc. v. United States, 436 F. Supp. 1314 (E.D.N.C. 1977), affd, 644 F.2d 879 (4th Cir. 1981), affd, 461 U.S. 574 (1983), was also decided in the Bob Jones opinion. Although the facts of Bob Jones and Goldsboro. differ to some extent, these differences are not essential to this Comment.

${ }^{74}$ See, e.g., Note, The Internal Revenue Service's Revocation of the Tax Exempt Status of a Private Religious College Does Not Violate the First Amendment, $50 \mathrm{U}$. CiN. L. Rev. 615, 625-27 (1981).

${ }^{75}$ See Note, The Internal Revenue Service's Treatment of Religiously Motivated Racial Discrimination by Tax Exempt Organizations, 54 NOTRE Dame Law. 925 (1979); see also Laycock, Tax Exemptions for Racially Discriminatory Religious Schools, 60 TEX. L. REv. 259 (1982) (asserting that discriminatory religious schools should be granted tax exemptions up to the point at which they begin to defeat public school desegregation; at this point a court may legitimately revoke the school's tax exemption).

${ }^{76}$ See, e.g., Simon, The Tax-Exempt Status of Racially Discriminatory Religious Schools, 36 TAX L. REv. 477 (1981); Comment, The Tax-Exempt Status of Sectarian Educational Institutions that Discriminate on the Basis of Race, 65 IowA L. REv. 258 (1979). 


\section{B. The Supreme Court's Decision in Bob Jones}

A legal cynic viewing the Supreme Court's options in Bob Jones might conclude that the result in the case was preordained: public opinion demanded that the Court revoke federal tax exemptions for racially discriminatory schools. The reasoning used to support this result, however, was not so readily predictable. For example, the Court could have carved out a narrow exception for organizations that act in clear violation of public policy. Instead, the Court construed the statute as imposing a much broader requirement: that organizations receiving an exemption provide an affirmative public benefit to society. This latter approach-the establishment of a "public benefit rule"-represents a substantial refinement that could provide a unified treatment of organizations claiming a section 501(c)(3) exemption.

Although some of the language in Bob Jones is ambiguous, the basic structure of the Court's analysis is relatively straightforward. In essence, the Court advances a two-part test for exemptions under section 501(c)(3). First, "an institution must show . . . that it falls within one of the eight categories expressly set forth in that section." ${ }^{\prime 77}$ Second, and more controversially, "an institution seeking tax-exempt status must serve a public purpose and not be contrary to established public policy."78 This second prong was developed by importing the commonlaw principles traditionally applied to charitable trusts; "charities were to be given preferential treatment because they provide a benefit to society." In short, under the Bob Jones test, the organization "must demonstrably serve and be in harmony with the public interest."

Thus, despite the fact that the drafters of section 501(c)(3) used the disjunctive "or" to separate the eight categories" - leaving open the argument that an institution within one of the specified categories is entitled to exemption regardless of whether it qualifies as "charitable" ${ }^{82}$-the Court required that every organization seeking exemption

77 Bob Jones, 461 U.S. at 585. The eight categories referred to by the Court are religious, charitable, scientific, testing for public safety, literary, educational, fostering national or international amateur sports competition, and preventing cruelty to children or animals. See I.R.C. § 501(c)(3) (1982).

${ }^{78}$ Bob Jones, 461 U.S. at 586.

79 Id. at 589.

$80 \mathrm{Id}$. at 592 .

81 See I.R.C. $\S 501$ (c)(3) (1982) (permitting tax exemptions for organizations that are "organized and operated exclusively for religious, charitable, scientific, testing for public safety, literary, or educational purposes, or to foster national or international sports competition ... or for the prevention of cruelty to children or animals") (emphasis added). 86.

${ }_{82}$ The Bob Jones Court specifically rejected this argument. See 461 U.S. at 585- 
under that section confer a charitable benefit upon society. The Court then applied this requirement to Bob Jones University. While the University unquestionably met the first prong of the test, it failed to pass the second: "Racially discriminatory educational institutions cannot be viewed as conferring a public benefit within the 'charitable' concept ... or within the congressional intent underlying $\S 170$ and $\S 501$ (c)(3)." 83 The revocation of Bob Jones University's tax exemption was thus affirmed. ${ }^{84}$

\section{Reactions to the Court's Opinion}

As might be expected, the Court's rather innovative formulation of the public benefit rule induced considerable critical commentary. Many discussions of the decision following the Court's 1982-1983 term noted potential sources of controversy. ${ }^{85} \mathrm{~A}$ number of authors, while agreeing in substance with the Court's judgment, were troubled by certain aspects of the majority's opinion. In particular, several of the articles at-

8s Id. at 595-96.

84 The majority attempted to limit somewhat the scope of its public benefit analysis. "We emphasize," the Court said, "that these sensitive determinations should be made only where there is no doubt that the organization's activities violate fundamental public policy." Id. at 598; see also id. at $596 \mathrm{n} .21$ ("WW]e need not decide whether an organization providing a public benefit and otherwise meeting the requirements of $\S 501(c)(3)$ could nevertheless be denied tax-exempt status if certain of its activities violated a law or public policy."). Despite this admonition, however, the Court used much broader language elsewhere in the opinion and articulated a view of the purpose of section 501(c)(3) consistent with an affirmative public benefit requirement. See infra text accompanying notes 93-99.

ss See Note, Denial of Tax Exempt Status for Racially Discriminatory Schools, 17 Akron L. REv. 161 (1983) (agreeing that exemptions from taxation under the Internal Revenue Code are not applicable to religious schools that discriminate on the basis of race); Note, Bob Jones University v. United States-No Tax Exemptions for Racially Discriminatory Schools: Supreme Court Clarifies Thirteen-Year Policy Imbroglio, 11 J. Coll. \& UNIV. LAW 69, 82 (1984) (concluding that, although several unanswered questions remain, "the majority opinion appears both legally and logically sound"); Note, The Internal Revenue Service Has the Power to Revoke the Tax-Exempt Status of Private Schools Which Practice Racial Discrimination Due to Religious Belief, Since These Schools Are Not Charitable, and Revocation Does Not Violate the Free Exercise or the Establishment Clauses of the First Amendment, 29 VILL. L. REv. 253, 277 (1984) (agreeing that "the Court properly construed the exemption provision to restrict tax-exempt status to those institutions that do not engage in racial discrimination"); Note, Educational Institutions Which Practice Race Discrimination in Accordance with Sincere Religious Beliefs are Disqualified for a Federal Tax Exemption, 23 WASHBURN L.J. 463, 468 (1984) (suggesting that "the policy for desegregation must be balanced against . . . freedom of religion before tax exemption can be denied to schools which practice racial discrimination under religious beliefs"); see also The Supreme Court, 1982 Term: Tax-Exempt Status of Discriminatory Private Schools, 97 HARv. L. REv. 261 (1983) (reviewing the Bob Jones decision and pointing out the failure of the Court to dispose adequately of the constitutional arguments lurking in the case). 
tacked the allocation of decisionmaking in the case among the courts, the IRS, and Congress. ${ }^{86}$ Two pieces commented on the "pragmatic jurisprudence" practiced by the Court in the case, ${ }^{87}$ while another bemoaned the pressing constitutional questions left unanswered. ${ }^{88}$

The vast majority of authors commenting upon Bob Jones were thus in substantial agreement with the Court's decision, although many disagreed with the reasoning employed to reach that result. Only a small minority, however, undertook any sort of prospective analysis of the ramifications of the opinion. One author found the "tax benefit principle" announced by the Court in large measure unworkable, and predicted that the principle would receive only limited application. ${ }^{\mathbf{8 9}}$ Another author cautioned that

by allowing governments to condition assistance to religious organizations that are not "purely religious" on the observance by those organizations of public policies, and to closely scrutinize the activities of the recipient organizations, Bob Jones will lead to an unhealthy degree of governmental supervision of religious organizations seeking to retain govern-

${ }^{88}$ See Dye \& Webster, Supreme Court in Bob Jones Holds that Exempt Organizations Are Bound by Law of Charity, $59 \mathrm{~J}$. TAx'N 70, 74 (1983) (suggesting that "[i]t would seem more sensible and efficient for Congress to decide which . . . bases of discrimination, if any, are sufficiently fundamental and free from doubt to justify inclusion as criteria for exempt status"); Galvin \& Devins, A Tax Policy Analysis of Bob Jones University v. United States, 36 VAND. L. REv. 1353, 1355, 1379 (1983) (recommending that "Congress act definitively to take the lead in formulating tax policy" and cautioning that "courts should not supplant the role of Congress as lawmaker by making broad tax policy pronouncements, but should oversee the IRS to ensure that it properly implements and enforces the tax laws"); Note, Bob Jones University v. United States: Segregated Sectarian Education and IRC Section 501(c)(3), 62 N.G.L. REv. $1038,1045-46$ (1984) (asserting that the Court overstepped the bounds of its allocated powers in giving section 501(c)(3) a strained interpretation, and arguing that the matter was better left to the legislative branch).

87 See Nathan, Reflections on Pragmatic Jurisprudence: A Case Study of Bob Jones University v. United States, 22 AM. Bus. L.J. 227, 229 (1984) (arguing that Bob Jones represents "pragmatic result-oriented jurisprudence," and that, "although hardship to certain individuals may have been relieved by the case's final resolution, the reasons for the courts' value preferences and guidance for future cases are missing from the decisions"); Note, Bob Jones University v. United States: Paying the Price of Prejudice-Loss of Tax Exempt Status, 35 MERCER L. REv. 937, 962-63 (1984) (maintaining that the outcome in the case was to some extent predetermined because " $[t]$ he overriding national policy concerning racial discrimination in education demanded that the University be denied the tax exemption it sought").

${ }^{88}$ See Note, Religious Schools, Public Policy, and the Constitution: Bob Jones University v. United States, 62 N.C.L. REv. 1051, 1067 (1984) (agreeing with the decision but warning that "the Court has merely postponed resolution of . . . troubling constitutional questions" concerning the school's freedom of religion and the government's interest in eradicating discrimination in education).

${ }^{89}$ See Truesch, Bob Jones-Where Now?, 62 TAxes 43, 51 (1984). 
mental assistance. ${ }^{90}$

Finally, one student commentator foresaw a danger that "the federal government might, in a less tolerant era, construe Bob Jones in such a way as to justify official repression of certain religious groups or other organizations."91 While agreeing with the Court's decision, the author wrote that the Court's failure to limit the future application of the public benefit requirement "has left the lower courts and the IRS to develop new, unpredictable limitations on charities."92

\section{The Scope of the Public Benefit Rule}

In the absence of further guidance by the Supreme Court or compelling arguments from the academic community, one is left to ponder the scope of the public benefit rule. Isolated statements in Bob Jones purport to limit the application of the rule to instances in which there is "no doubt" that a tax-exempt organization is acting contrary to fundamental public policy. ${ }^{98}$ Yet other aspects of the opinion suggest the appropriateness of a much broader reading.

First, the Bob Jones Court articulated a rationale for section 501 (c)(3) that is clearly consistent with the imposition of an affirmative public benefit requirement:

Congress sought to provide tax benefits to charitable organizations, to encourage the development of private institutions that serve a useful public purpose or supplement or take the place of public institutions of the same kind.

Tax exemptions for certain institutions thought beneficial to the social order of the country as a whole, or to a particular community, are deeply rooted in our history, as in that of England. . . .

... [Statements by English and American courts] clearly reveal the legal background against which Congress enacted the first charitable exemption statute in 1894: charities were to be given preferential treatment because they provide a benefit to society. ${ }^{94}$

90 Schachner, Religion and the Public Treasury After Taxation with Representation of Washington, Mueller, and Bob Jones, 1984 UTAH L. REv. 275, 311-12.

81 Note, Applying a Public Benefit Requirement to Tax-Exempt Organizations, 49 Mo. L. Rev. 353, 371 (1984). This Note identifies theoretical drawbacks to the public benefit rule but does not attempt to apply the rule to any specific factual situations.

${ }^{82}$ Id. at 367.

9s See Bob Jones, 461 U.S. at 592, 598.

24 Id. at 588-89 (emphasis added). 
This rationale clearly suggests that section 501(c)(3) would exclude not only those organizations that act "contrary" to public policy, but also those failing in other ways to provide a public benefit. The strongest counterargument to this interpretation - that the text of the provision precludes the imposition of an affirmative requirement-was rejected by the Court in its refusal to give a literal reading to the disjunctive "or" between "charitable" and other categories of section 501(c)(3). ${ }^{95}$

A comparison of the majority and concurring opinions in $B o b$ Jones provides additional support for a broad reading of the case. Justice Powell concurred in the Court's judgment that tax exemptions should be denied to private schools that practice racial discrimination. ${ }^{96}$ Powell refused to join much of the Court's opinion, however, primarily because he viewed the opinion as imposing an affirmative public benefit requirement: "With all respect, I am unconvinced that the critical question in determining tax-exempt status is whether an individual organization provides a clear 'public benefit' as defined by the Court."'97 The seven Justices endorsing the majority opinion could have taken the more narrow approach adopted by Powell and invoked common-law concepts of charity, if at all, only for denying exemptions to organizations clearly violating public policy. Their failure to take this approach suggests a willingness to give considerably more force to the incorporation of a public benefit requirement in section 501(c)(3).

Under these circumstances, it seems most accurate to view the majority as imposing both a "public benefit" prescription and a "violation of public policy" proscription on institutions seeking section 501(c)(3) exemptions. ${ }^{88}$ Thus, in order to qualify for the exemption, an organization must come within the definition of "charitable" established by the Court, regardless of the type of activity pursued by the organization. ${ }^{99}$

${ }^{25}$ See id. at 585-86.

98 See id. at 606 (Powell, J., concurring).

${ }^{87}$ Id. at 608 .

${ }^{88}$ Cf. Note, supra note 91 , at 358 (arguing that the public policy requirement should be treated as a corollary to the public benefit requirement: "Contravention of public policy is merely a factor in determining if a net benefit exists."). See generally Note, Bob Jones University v. United States: Closing the Sectarian Loophole in Private Education, 11 OHo N.U.L. REv. 217, 229 (1984) (asserting that, in constructing the public benefit and public policy requirements, "the Court unnecessarily went beyond the issues before it in establishing what will prove to be an extremely controversial and impractical test").

${ }^{99}$ The Court suggested that the scope of its opinion might be limited to "educational" organizations: "We deal here only with religious schools-not with churches or other purely religious institutions . . ." 461 U.S. at 604 n.29. Nevertheless, neither the Court's primary finding - that the exemption applies to organizations providing a public benefit-nor its treatment of the text of section 501(c)(3) provides any basis for distinguishing educational institutions from the other types of organizations described in the statute. One possible constitutional distinction, based on the free exercise and 
The next section outlines the application of this rule to profitable religious enterprises.

\section{Application of the Public Benefit Rule to PE'R Publishing}

As explained above, ${ }^{100}$ the Court of Appeals for the Third Circuit applied a conventional two-part test in deciding $P \mathcal{E} R$ Publishing. This two-part test looked to the purpose of the organization and to the inurement of the benefits of the organization's activity. Nowhere in the Third Circuit's opinion is there mention of any public benefit conferred by $\mathrm{P} \& \mathrm{R}$. Yet, after Bob Jones, such a public benefit is a sine qua non of tax-exempt status conferred by section 501(c)(3). Had the Third Circuit applied the public benefit rule to $P \& R$, the court would have denied, rather than upheld, tax-exempt treatment for religious publishing houses.

\section{A. Operation of the Public Benefit Rule}

P\&R was operated solely for the benefit of the Orthodox Presbyterian Church. The revenue generated from the sale of its literature was directed either to the expansion of the enterprise, thus furthering its proselytizing power, or to paying the salaries and operating costs of the organization itself. By the terms of its own charter, $P \& R$ was required to use any surplus income "to improve its publication, extend their [sic] influence, or assist institutions 'engaged in the teaching or inculcating' of the 'system of belief and practice' of the Orthodox Presbyterian Church (OPG)."101

However sincere in religious fervor, the announced principles and actual practices of $P \& R$ Publishing confer no discernible benefit upon the public at large. Certainly, the company's literature does add to the "marketplace of ideas," but so do the works printed by countless other publishers not eligible for special tax exemptions. The only real beneficiaries of P\&R's literary efforts are the select few who enjoy reading the company's publications. Even these readers must pay for the privilege of perusing $P \& R$ 's publications. While the spirits of $P \& R$ 's readers are, no doubt, uplifted by the publisher's message, so too are the readers of Plato and Keats inspired; yet the publishers of Plato and Keats receive no exemptions.

establishment clauses, is discussed later in this Comment. See infra text accompanying notes 104-24.

${ }_{100}$ See supra text accompanying notes 14-27.

101 PER Publishing, 743 F.2d at 150 (quoting P\&R's charter). 
Applying the test articulated in Bob Jones to PER Publishing, one must conclude that the publisher does not satisfy the standard of "charity" required for an exemption under section 501(c)(3). Unlike many religious activities, sectarian publishing serves no altruistic purpose. Halfway houses, inner-city ministries, and famine relief organizations that are religiously affiliated should, and do, receive tax exemptions for the income they raise. These activities provide truly humanitarian services for the underprivileged and malnourished of our society. There is a distinct difference between the benefits conferred by these groups and the market-oriented offerings of religious publishers.

The instinctive desire to assist bona fide charitable institutions goes far in explaining why the public benefit rule is an improvement over the inconsistent case law that preceded it. Under the former "operated exclusively for a religious purpose" doctrine, profitmaking enterprises as well as philanthropic organizations were eligible for tax exemptions. No public policy is served by granting such disparate entities identical treatment. The public benefit rule, by requiring that petitioning organizations serve a charitable purpose, more accurately selects those deserving tax-exempt status. ${ }^{102}$ Furthermore, adoption of the public benefit rule would dispense with the need for the wide variety of tests now administered under section 501(c)(3). Bob Jones prescribes a threshold examination for public benefit that will more easily resolve a number of difficult cases that come before the courts.

Acceptance and full-scale application of the Bob Jones test will undoubtedly lead to the revocation of tax exemptions for many religious organizations. In doing so, it may make the charitable organizations that retain exempt status more attractive donees. The resulting reallocation of resources would provide increased support for the charitable activities that society needs most desperately.

It is likely that any implementation of the public benefit rule to religious institutions would meet strong resistance. Apart from the statutory arguments discussed in Bob Jones, ${ }^{103}$ two constitutional quagmires, both grounded in the religion clauses of the first amendment, must be traversed. Neither constitutional argument, however, presents a

\footnotetext{
${ }^{102}$ Cf. Bob Jones, 461 U.S. at 587-90 (discussing reasons for granting charitable exemptions).

${ }_{103}$ See supra text accompanying notes 81-84; see also Bob Jones, 461 U.S. at 61223 (Rehnquist, J., dissenting). Justice Rehnquist argued that section 501(c)(3) provided little support for the Court's position and that the Court's reliance on section 170(c) of the Internal Revenue Code was misplaced. See id. at 613-14. He also contended that the legislative history of section 501(c)(3) made clear that Congress had decided which types of organizations serve a public purpose and identified them in the provision's specific language. See id. at 614-22.
} 
serious obstacle to the application of the public benefit rule.

\section{B. The Free Exercise Clause}

The most obvious constitutional argument against denying tax exemptions to religious publishers is that it would inhibit the free exercise of religion in contravention of the first amendment. ${ }^{104}$ By refusing to grant an exemption, a publisher would contend, the Court places a heavy economic burden on the dissemination of religious literature. Many publishers, finding their exemptions revoked, might cease operating altogether. These publishers would argue that, although the government is not directly restricting free expression of religious ideas, it is doing so indirectly by making expression economically infeasible.

This argument, however superficially appealing, finds little support in the case law. Although the Supreme Court has held that property tax exemptions for religious institutions do not contravene the establishment clause, ${ }^{108}$ the Court has never ruled that the free exercise clause compels such exemptions. Indeed, it is difficult to see how such a ruling could be justified. Religious publishers subjected to taxation are still free to conduct whatever dissemination activities they wish; they simply have lost government subsidization of these endeavors.

Lower courts that have confronted this question have agreed that the withdrawal of an exemption does not implicate religious guarantees. In Parker $v$. Commissioner, ${ }^{106}$ the Court of Appeals for the Eighth Circuit held that

[t]he receiving of an exemption is . . a matter of legislative grace and not a constitutional right. As long as exemptions are denied by the Commissioner on a non-discriminatory basis using specific and reasonable guidelines and without inquiry into the merits of the particular religious doctrines, the withholding of religious exemptions is permissible under the Constitution. ${ }^{107}$

Similarly, in Incorporated Trustees of the Gospel Worker Society $v$. United States, ${ }^{108}$ a district court upheld revocation, stating that the plaintiff had failed to demonstrate that the action was in any way based

104 See U.S. CoNST. amend. I, cl. 1 (providing that "Congress shall make no law respecting an establishment of religion, or prohibiting the free exercise thereof").

105 See Walz v. Tax Comm'n, 397 U.S. 664, 673-80 (1970).

108365 F.2d 792 (8th Cir. 1966).

107 Id. at 795.

108510 F. Supp. 374 (D.D.C), affd mem., 672 F.2d 894 (D.C. Cir. 1981), cert. denied, 456 U.S. 944 (1982). 
on a judgment of the merits of the plaintiff's religious tenets. Without such a showing, the court said, the revocation was permissible under the Constitution. ${ }^{109}$

Even if the Supreme Court did determine that the revocation of tax-exempt status inhibits the free exercise of religion, the revocation may nevertheless be permissible. The Court's opinion in Bob Jones reaffirms the doctrine that a compelling state interest may justify a limitation on religious liberty. The Court held that the state's fundamental interest in eradicating racial discrimination substantially outweighed whatever encumbrances were placed upon the University's religious practices by the revocation of tax-exempt status. ${ }^{110}$ Although certainly not as fundamental as equal access to education, the government's interest in seeing that its tax laws are evenly and effectively applied is constitutionally sufficient to outweigh the marginal free exercise rights restricted by the imposition of a tax on religious publishers. As the Court said in United States $v$. Lee, ${ }^{111}$ "[b]ecause the broad public interest in maintaining a sound tax system is of such a high order, religious belief in conflict with the payment of taxes affords no basis for resisting the tax."112

Thus, regardless of whether the Court decided that religious liberties may be implicated by revocation of tax exemptions, taxes imposed in a just and nondiscriminatory fashion simply do not constitute prohibitions on the free exercise of religion sufficient to warrant consti-

100 See id. at 380; see also Winters v. Commissioner, 468 F.2d 778, 781 (2d Cir. 1972) (citing First Nat'l Bank \& Trust Co. v. United States, 115 F.2d 194 (5th Cir. 1940)) (asserting that "[i]t is firmly established that benefits to taxpayers such as deductions for contributions to charitable organizations, are matters of legislative grace; there is no constitutional right to a tax deduction").

110 See Bob Jones, 461 U.S. at 604; see also, e.g., United States v. Lee, 455 U.S. $252,257-58$ (1982) ("The state may justify a limitation on religious liberty by showing that it is essential to accomplish an overriding governmental interest."); Wisconsin v. Yoder, 406 U.S. 205, 214 (1972) (holding that the state, in order to compel school attendance beyond the eighth grade against a claim by members of the Amish religion that such attendance interfered with their religious beliefs, had to show "a state interest of sufficient magnitude"); Sherbert v. Verner, 374 U.S. 398, 406-07 (1963) (holding that no compelling state interest was enforced by a state statute that withheld unemployment benefits from claimants who refused to work on Saturdays because of religious beliefs).

111455 U.S. 252 (1982).

112 Id. at 260; see also In re Albert Lindley Lee Memorial Hosp., 209 F.2d 122, 124 (2d Cir. 1953) (holding that "[t]he public interest in the collection of taxes . . . outweighs the private interest of [a] patient" who is required to give the IRS information about fees paid to her physician); Harper v. United States, 587 F. Supp. 1056, 1058 (E.D. Pa. 1984) (upholding the imposition of a penalty on a taxpayer whose refusal to pay taxes was based on his conscientious religious objections to war because "[t]he government's interest in the efficient collection of taxes due outweighs the minimal infringement of ... First Amendment rights"). 
tutional protection.

\section{The Establishment Clause}

A more subtle argument, centering on the establishment clause, might also be advanced by religious publishers. In Lemon v. Kurtzman, ${ }^{113}$ the Supreme Court interpreted the establishment clause as imposing a three-pronged restriction on governmental activity: state actions must have a secular purpose, must neither advance nor inhibit religion, and must not lead to excessive entanglement with religious conduct. ${ }^{114}$ Relying on the excessive entanglement prong, religious publishers might assert that the imposition of taxes on their operations would unconstitutionally enmesh government with religion.

This excessive entanglement claim would receive only thin support from prior cases. Traditionally, the establishment clause has served as a barrier to government aegis of religious entities and to any preference for one religion over another. In the case of revocation of publishers' exemptions, no conceivable benefit redounds to religious groups. If anything, religious organizations will be hindered by losing their tax exemptions. The free exercise clause, rather than the establishment clause, would logically underlie the constitutional right at issue. ${ }^{115}$

Supreme Court support for such an unusual use of the establishment clause is arguably found in Justice Brennan's concurrence in $M c$ Daniel v. Paty. ${ }^{116}$ The majority in McDaniel found that a state violated the free exercise clause by prohibiting ministers from serving in the state legislature. ${ }^{117}$ Writing separately, Brennan argued that establishment clause guarantees were also implicated. ${ }^{118} \mathrm{He}$ perceived a harmful degree of government involvement where a state was allowed to determine, on religious grounds, qualifications for state office.

Brennan's opinion in McDaniel is atypical of the analysis found in most "excessive entanglement" cases. The routine opinion involves a finding of some sort of affirmative governmental action that unacceptably assists religion. In Wolman $v$. Walter, ${ }^{119}$ for example, the Court found excessive entanglement in parts of a state statute that authorized the provision of certain materials and services to parochial schools. ${ }^{120}$

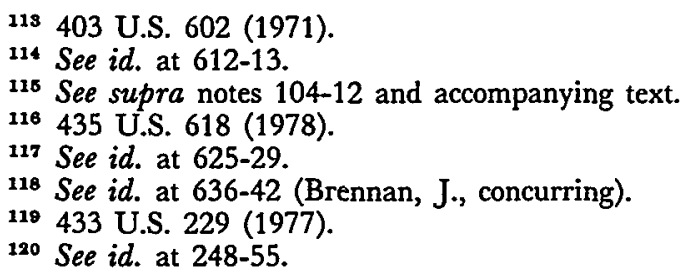


In a similar manner, the Court in Larkin v. Grendel's Den ${ }^{121}$ struck down a state statute that delegated to the governing bodies of churches the power to prevent issuance of liquor licenses to nearby premises. The Court held that the statute created excessive entanglement between the state and the churches. ${ }^{122}$

Even if one were to accept the novel proposition that the establishment clause can be violated by nondiscriminatory governmental measures that impede religious organizations, the minimal intrusion involved in revoking an exemption and administering a tax is not sufficiently "entangling" to rise to the level of a violation. In Walz $v$. Tax Commission, ${ }^{123}$ the Supreme Court upheld property tax exemptions for religious institutions. The Court specifically found that tax exemptions are not aimed at establishing or supporting religion and that they create only a minimal involvement between church and state. ${ }^{124}$ The intrusion of the state in administering a tax exemption-including the filing and approval of necessary forms-seems comparable to the intrusion required for administering the tax itself. Thus, if granting a tax exemption would not constitute excessive entanglement, neither would revoking the exemption.

In sum, then, neither the free exercise clause nor the establishment clause presents a serious constitutional impediment to the revocation of tax-exempt status for religious publishers.

\section{CONCLUSION}

Each year over one hundred thousand organizations file for income tax exemptions under section 501 (c)(3). ${ }^{125}$ Historically, the criteria for granting tax-exempt status under that section were muddled and incapable of consistent application. Moreover, they conferred exemptions on profitmaking institutions not engaged in charitable activities. The public benefit rule articulated by the Supreme Court in Bob Jones University $v$. United States is a welcome improvement, because it clari-

121459 U.S. 116 (1982).

122 See id. at 126-27; see also Committee for Pub. Educ. v. Nyquist, 413 U.S. 756, 794-98 (1973) (striking down on excessive entanglement grounds a New York statute establishing financial aid programs for private and parochial schools); Lemon v. Kurtzman, 403 U.S. 602, 614 (1971) (finding excessive entanglement in state statutes supplementing the wages of parochial school teachers and reimbursing parochial schools for textbooks and instructional materials).

123397 U.S. 664 (1970).

124 See id. at 672-76.

${ }_{125}$ See Bob Jones Univ. v. United States, 461 U.S. 574, 608 (1983) (Powell, J., concurring) (citing InTERnal Revenue Service, 1982 Exempt Organization/ Business MASTER File). 
fies the requirements for such exemptions and provides exempt status only to deserving organizations.

In Presbyterian $\mathcal{E}$ Reformed Publishing Co. v. Commissioner, the Court of Appeals for the Third Circuit had the opportunity to extend this public benefit rule to religious publishers. By declining to do so, the court added yet another case to the curious melange of exemption decisions. When the Supreme Court next considers this issue, it should render guidance to the lower courts by employing the public benefit rule and stressing its applicability to all organizations claiming exemptions under section 501(c)(3). 